\title{
Correlation between Left Ventricular Diastolic Dysfunction and Dyslipidemia in Symptomless Patients with Newly Diagnosed Diabetes Mellitus-II
}

\author{
HESHAM EL SAYED LASHIN, M.D.*; ABULFETOUH EID ALENANY, M.D.** and \\ MUSTAFA MOHAMED ELSANDAROSY, M.D.***
}

The Departments of Internal Medicine*, Faculty of Medicine, Al-Azhar University, Microbiology \& Immunology**, Faculty of Medicine, Tanta University and Cardiology*** Department, MOH - Damietta

\begin{abstract}
Background: The frequency of heart failure (HF) in cases with Diabetes mellitus (DM) is elevated even in the nonattendance of hypertension (HTN) and coronary artery disorder (CAD).

Aim of Study: This study aims to investigate the prevalence of left-ventricular (LV) systolic and diastolic dysfunctions (DD) in symptom less cases with newly diagnosed DM-II, and assess the association among LVDD and dyslipidemia in those cases.

Subjects and Methods: This was a cross-sectional research involving cases with a new detected (within 1-yr) DM-II; all cases were aging from 30 to 60 -yrs, normo-tensive and clinically symptomless and visited the out-patient clinics of the endocrinology unit at Mustasharak Hospital from January 2020 to the end of June 2021, Demographic parameters, riskfactors and waist-hip ratio (WHR) were evaluated. Blood specimens for lab analyzing were collected. Comprehensive echo-cardiography has been done to assess systolic and diastolic functions (DF).

Results: LA size and volume index, de-acceleration time and E/e' were highly significant in DM-cases with HbA1c $>$ ?7.5 in comparison to diabetics with normal HbA1c. Meanwhile, $\mathrm{E}$ wave, E/A ratio and Isovolumetric relaxations time were low significantly in DM-cases with $\mathrm{HbA} 1 \mathrm{c}>$ > 7.5. Moreover, there was a highly significance change among the study groups in regard to diastolic function grades.

Conclusion: Diastolic dysfunction (DD) has a high prevalence in a newly detected DM-cases and looks to be associated positively with the HbA1c-levels, dyslipidaemia, obesity, and the DM period.
\end{abstract}

Key Words: Diastolic dysfunction - Left ventricular - DMII - Dys lip idemia.

Correspondence to: Dr. Hesham El Sayed Lashin, The Department of Internal Medicine, Faculty of Medicine, Al-Azhar University

\section{Introduction}

THE frequency of DM is risingall over the globeand quickly gaining epidemic features. Over the last 30-yrs, a variety of epidemiologic, clinical and autopsy researches have suggested the existence of diabetic heart disorder as a separate clinical entity. Diastolic heart failure (HF) is as well stated to as HF, with conserved left ventricular (LV) systolic functions. Several researches have concluded that the occurrence of HF in DM-cases is elevated even in the non-presence of HTN and CAD. Researches have concluded anelevated prevalence of pre-clinical diastolic dysfunctions (DD) between DM-cases [1].

DM-II is a metabolic disorder marked by hyperglycaemia and insulin resistances which share to variouscardio-vascular risk-factors, like dyslipidemia, HTN and obesity. DM-II is as well accompanied with unusually elevated inflammatory mediators and cytokines levels, and has vascular and renal complications. Together, these parametersrise the cardio-vascular risks in DM-cases [2]

Several authors consider LV diastolic dysfunction (LVDD) the initial manifestation of cardiac re-modeling in DM. DM and HF influence each other in a bi-directional way in the form of reason and outcomes [3]. 19\% of HF-cases are found to have DM-II, and the existence of DM-II rises the risk of HF two- to eight-times [4].

Diabetic cardio-myopathy was suggested as a self-governing cardio-vascular disorder, and several mechanisms, like micro-vascular disorders, autonomic dysfunctions, metabolic conditions, and interstitial fibrosis, were proposed as causative 
parameters. The evidence shows that myocardial damages in DM-cases influences DF sprevious to the systolic functions. The pathogenesis of this LV dysfunctions in DM-cases is unclearly explained [5].

Impaired LVDD has a high prevalence and have a significant function in the HF condition developments, mostly HF with conserved ejecting fraction. DD is as well accompanying with cardiovascular death in the general populace and cases with different cardiac disorders. LVDD frequently leads clinical presentations of overt cardiac disorder, and therefore, its early detection and suitable managing are significant [6].

Opportunely, this cardiac pre-clinical alteration in DD may be diagnosed using Doppler echocardiography. As the significance of the predictive value of LVDFs and connected HF was progressively identified, valuation of LVDF has been a routine process throughout echo-cardiography examinations [7].

The metabolic condition driving the identicalworld wide epidemics of DM-II and CVD there is an irresistible moral, medical and economical imperative to recognize those persons with metabolic conditions early, so that life-style intervention and treatment canstop the expansion of DM and/or cardio-vascular disorders [8]

The extensive range is mostly clarified by variable descriptions of LVDD, used echocardiography methods, and population features. As the rather elevated LVDD prevalence, a better considerate of its time-depending progress can recognize high-risk people in addition to create chances to avoid or at minimum post pone its development. However, longitudinal researches of the natural course of LVDF in DM-II-cases who were free from superficial cardio-vascular disorders need to be presented before this may be done [9].

LVDD is considered to be frequent in DM-IIcases, but data on its development over time is missing, we aim to study the incidences and stages of LVDD and dyslipidemia in symptom less newly diagnosed DM-II-cases.

\section{Subjects and Methods}

Study design This was a cross-sectional observational research was performed for 18 months from January 2020 to the end of June 2021, 1500 patients were screened for DM in a dedicated out- patient clinic at Mustasharak Hospital, Khamis Mushayet, KSA. A number of 750 patients were omitted built on our criteria of exclusion. Of the 750 cases who were employed to the research, 100 had noncomplete echo-cardiography or lab information, and 150 had no written agreement. These 250 cases were omitted, leaving 500 contributors for this work.

Cases with newly diagnosed DM were involved if they satisfy the next criteria:

1- Agesfrom 30 to 60-yrs.

2- Detected with DM-II within 1-yr.

3- Normotensive.

4- Symptomless of HF.

The exclusion criteria were cases with valvular or ischemic heart disorders, HTN (BP >130/80$\mathrm{mmHg}$ ), atrial fibrillation, HF (congestive HF or HF with conserved ejecting fraction), cardiomyopathy, renal failures, chronic pulmonary disorders, thyroid dysfunctions, severe anemia, hemoglobinopathies, taking any medications that mayinfluence LV functions or poor transthoracic echo window.

Cases were sorted regarding their HbAlc levels into 2 groups: Group I: 300 patients with $\mathrm{HbA} 1 \mathrm{c}$ HbA1c >7.5, and group II: 200 patients with HbA1c HbA1c < 7.5. Furthermore, we re-classified the studied group into 2 extrasub groups regarding the existence or nonexistence of LVDD.

\section{Study population:}

We involved 500 successive cases who met the criteria of inclusion for this work. Demographic features, medical history so as to eliminate any accompanying $\mathrm{CV}$ risk-factors and smoking state were evaluated.

Cases have been detected regarding the American Diabetes Association (ADA) rules [10]. These criteria for DM-II involve FBS > 126-mg/dL and 2-h plasma glucose >200-mg/dL through out an OGTT, RBS > 200-mg/dL with signs (polydipsia, polyphagia, polyuria, weight losing) and $\mathrm{HbA} 1 \mathrm{c}$ $>6.5 \%$. Height $(\mathrm{cm})$ and weight $(\mathrm{kg})$ were determined to find the BMI $\left(\mathrm{kg} / \mathrm{m}^{2}\right)$ and recognize obesity type as next: Under-weight was judged a BMI $<18.5$, ordinary $18.5-24.9$, over-weight 25.0 29.9, obese I 30.0-34.9, obese II 35.0-39.9, and extreme obese >-40 [11]

Waist circumferences (WC) with cut-off for large WC was $>850 \mathrm{~mm}$ for women and $>900 \mathrm{~mm}$ 
for men, and WHR with cut-off for lagre WHR was 0.9 for male and 0.8 for female [11].

BP was determined via a mercury sphygmomano-meter and was measured regarding the present ESC strategies in which HTN is definite as a systolic BP $\geq 140-\mathrm{mmHg}$ and/or diastolic BP $\geq 90$-mmHg [12]

ECG has been done on all cases to eliminate obvious ischemia or any chronic arrhythmias influencing LVDF.

The work's protocol was accepted by the IRB of the Faculty of Medicine in our University, Knowledge able written agreement was attained from all contributors.

Laboratory analysis:

Laboratory investigations including:

- CBC, ESR, serum creatinine, FBG, 2HPPG, $\mathrm{HbA} 1 \mathrm{c}, \mathrm{TC}, \mathrm{LDL}-\mathrm{C}, \mathrm{TG}$, HDL-C and CRP.

- Liver functions tests: ALT, AST, serum albumin, PT, PC, INR, serum bilirubin (total and direct).

Blood samples have been gathered there after atleast of 8 to 14 hours of over-night fasting to recognize cases with dyslipidemias, which is definite as the atherogenic lipid triad of the coexistence of increased triglycerides (TG) $>150-\mathrm{mg} / \mathrm{dl}$, elevated low-density lipoprotein (LDL-C)-particles $>130 \mathrm{mg} / \mathrm{dl}$ and decreased high-density lipoproteincholesterol (HDL-C) <40mg/dl level [13].

To evaluate glucose tolerance grade, all contributors with unknown DM-II experienced a 2 hours $75 \mathrm{~g}$ oral glucose tolerance testing, and the definition of DM-II was recognized regarding 2016 ADA criteria [10]

\section{Glycated hemoglobin (HbAlc) measurements:}

The blood specimens were gathered and kept at $2-8^{\circ} \mathrm{C}$ in $\mathrm{K}$-ethylenediamine tetra-acetic acid (K-EDTA) tubes via a Tosoh G8 HPLC analyzer (Tosoh Corporation). The examination was done only after ward exclusions of anemia. Cases who had level $>6.5 \%$ were judged to have DM regarding the ADA [10]

\section{Echo-cardiography valuation and factors:}

Echo-cardiography examination was done on the US device via a 2-to-4 MHz transducer. The values of all echo-cardiography factors were attained as the average value of 5 successive cardiac cycles. The LV end-systolic (LVESD) and enddiastolic diameter (LVEDD), septum width (IVS), the LV free-wall (PWT), and the left atrium (LA) diameters were determined regarding the references of the Echo-cardiography American Society [14] End-systolic and end-diastolic sizes and factors of systolic functions (ejecting fraction-EF, and fractional shortening-FS) were via the Teicholzequation. Relative wall thickness (RWT) was determined as $\left(2^{\circ}\right.$-PWT $) / L V E D D$. The LV-mass was determinedvia the Penn equation: $\mathrm{LV}$ mass $=1.04^{\circ}$. [(LVEDD+PWTD+IVS)3 (LVEDD)3]13.6g(14). The LV mass index (LV-mass/Ht2.7) was determined as the ratio of the LV mass and height2.7. The LV hypertrophy was definite as LV- mass/ $\mathrm{Ht} 2.7$ $\geq 51 \mathrm{~g} / \mathrm{m} 2.7$ for men and $\geq 49.5 \mathrm{~g} / \mathrm{m} 2.7$ for females. The analysis of trans-mitral inflowing speeds was gotten by pulsed-wave Doppler in the apical 4chamber viewing with the sample sizelocated at the mitral valve leaflet tips. Measures involved trans-mitral early diastolic (E-wave) and atrial (Awave) speeds that have been utilized to determine E/A ratio and E-wave de-acceleration time (DT). Criteria utilized for DD of heart: That can be any of the next; E/A ratio 2, DT $220 \mathrm{~ms}$ or VRT $95 \mathrm{~ms}$ d. d.E/e' > 10 .

\section{Statistical analysis:}

Categorical data have been introduced in the form of count and percentage and matched using Pearson's chi-square or Fischer's exact tests if the predictable cell counts for a $2 \times 2$ table was $<5$. The normally distributions of continuous data were exanimated via the Kolmogorov-Smirnov testing. Continuous data and data with normal distribution are given as the mean \pm SD (standard deviation) and have been matched via a two-tailed un-paired $t$-testing. Associations were Spearman's association coefficient testing. Uni-variable and multi-variable binary logistic regression models have been done to characterize DD predictors. Multi-variable regressions have been done via only variables with $p<0.05$ in the uni-variable regressing analyzing. Uni-variable regression analyzing have been donevia all clinically and laboratory guides. KaplanMeier survival curves have been done to evaluate the correlation among DD and period since diagnosing of DM. All $p$-values were 2-tailed, and statistically significance was judged at if $p<0.05$. All analyses have been done using IBM-SPSS24.0 package (Inc., Chicago, Illinois).

\section{Results}

This table shows that BMI and lipid profile (except HDL) were highly significant in DM-cases with $\mathrm{HbA} 1 \mathrm{c} \geq 7.5$ in comparison to diabetics with normal HbA1c. Meanwhile, HDL was low significance in DM-cases with $\mathrm{HbA1c} \geq 7.5$. 
Table (1): Demographic features of the studied cases.

\begin{tabular}{llll}
\hline & $\begin{array}{c}\text { HbA1c } \geq 7.5 \\
(\mathrm{n}=300)\end{array}$ & $\begin{array}{c}\text { HbA 1 c <7.5 } \\
(\mathrm{n}=200)\end{array}$ & $p$ \\
\hline Age (years) & $51.76 \pm 5.62$ & $52.28 \pm 4.74$ & 0.281 \\
Sex, $N(\%):$ & & & \\
$\quad$ Male & $156(52 \%)$ & $98(49 \%)$ & 0.511 \\
Female & $144(48 \%)$ & $102(51 \%)$ & \\
Waist circumference & $104.5 \pm 15.8$ & $102.6 \pm 16.1$ & 0.055 \\
(cm) & & & \\
WHR & $0.906 \pm 0.078$ & $0.893 \pm 0.086$ & 0.081 \\
BMI (kg/m $\left.{ }^{2}\right)$ & $31.17 \pm 4.28$ & $29.69 \pm 3.41$ & $0.000^{*}$ \\
Duration of DM & $7.16 \pm 4.35$ & $6.48 \pm 3.46$ & 0.064 \\
(months) & & & \\
Smoking, $(\%):$ & $133(44.3 \%)$ & $72(36 \%)$ & 0.063 \\
Treatment, $n(\%):$ & & & \\
Insulin & $97(32.3 \%)$ & $69(34.5 \%)$ & \\
OHD & $198(66 \%)$ & $121(60.5 \%)$ & 0.075 \\
OHD \& insulin & $5(1.7 \%)$ & $10(5 \%)$ & \\
Creatinine (mg/dl) & $0.903 \pm 0.243$ & $0.862 \pm 0.216$ & 0.054 \\
Urea (mg/dl) & $28.63 \pm 6.19$ & $27.38 \pm 6.72$ & 0.411 \\
Albumin (g/dl) & $4.01 \pm 0.994$ & $4.12 \pm 0.878$ & 0.205 \\
TC (mg/dl) & $206.1 \pm 35.15$ & $187.11 \pm 31.69$ & $0.000 *$ \\
TG (mg/dl) & $194.8 \pm 41.16$ & $178.45 \pm 36.53$ & $0.000^{*}$ \\
LDL (mg/dl) & $93.5 \pm 23.83$ & $78.54 \pm 25.16$ & $0.000^{*}$ \\
HDL (mg/dl) & $46.92 \pm 7.71$ & $50.4 \pm 8.46$ & $0.000 *$ \\
\hline
\end{tabular}

*Significant difference level $<0.05$.

Table (2): Comparing among studied groups as regard Echocardiography findings.

\begin{tabular}{|c|c|c|c|}
\hline & $\begin{array}{l}\mathrm{HbA} 1 \mathrm{c} \geq 7.5 \\
\quad(\mathrm{n}=300)\end{array}$ & $\begin{array}{l}\mathrm{HbA} 1 \mathrm{c}<7.5 \\
(\mathrm{n}=200)\end{array}$ & $p$ \\
\hline $\mathrm{EF} \%$ & $65.43 \pm 6.13$ & $64.97 \pm 4.88$ & 0.374 \\
\hline FS\% & $34.85 \pm 4.15$ & $53.24 \pm 3.77$ & 0.286 \\
\hline Left atrium size $(\mathrm{cm})$ & $3.75 \pm 0.509$ & $3.62 \pm 0.463$ & $0.004 *$ \\
\hline $\begin{array}{l}\text { Left atrium volume } \\
\text { index }\left(\mathrm{ml} / \mathrm{m}^{2}\right)\end{array}$ & $31.28 \pm 4.33$ & $28.97 \pm 3.46$ & $0.000 *$ \\
\hline E wave $(\mathrm{cm} / \mathrm{s})$ & $52.78 \pm 17.52$ & $56.57 \pm 15.49$ & $0.013 *$ \\
\hline E/A ratio & $1.02 \pm 0.413$ & $1.13 \pm 0.351$ & $0.002 *$ \\
\hline $\begin{array}{l}\text { De-acceleration time } \\
(\mathrm{ms})\end{array}$ & $221.45 \pm 73.5$ & $204.31 \pm 56.42$ & $0.005 *$ \\
\hline $\begin{array}{l}\text { Isovolumetric } \\
\text { relaxations time }(\mathrm{ms})\end{array}$ & $88.14 \pm 29.45$ & $97.44 \pm 28.15$ & $0.001 *$ \\
\hline E/é & $10.35 \pm 3.11$ & $9.76 \pm 2.72$ & $0.029 *$ \\
\hline \multicolumn{4}{|l|}{$\begin{array}{l}\text { Diastolic function, } \\
n(\%):\end{array}$} \\
\hline Normal & $91(30.3 \%)$ & $115(57.5 \%)$ & \multirow{3}{*}{$0.000 *$} \\
\hline DDG I & $159(53 \%)$ & $74(37 \%)$ & \\
\hline DDG II & $50(16.7 \%)$ & $11(5.5 \%)$ & \\
\hline
\end{tabular}

*Significant difference level $<0.05$.

This table shows that LA (left atrial) size and volume index, de-acceleration time and E/e' were highly significant in DM-cases with $\mathrm{HbA} 1 \mathrm{c} \geq 7.5$ in comparison to diabetics with normal HbA1c. Meanwhile, E wave, E/A ratioand isovolumetric relaxations time were low significantly in DMcases with $\mathrm{HbA} 1 \mathrm{c} \geq 7.5$. Moreover, there was a highly significance change among the groups regrading diastolic function grades.
Table (3): Comparison between LVDF and other parameters in studied groups.

\begin{tabular}{|c|c|c|c|}
\hline & $\begin{array}{l}\text { Diastolic } \\
\text { dysfunction } \\
(n=294)\end{array}$ & $\begin{array}{l}\text { Normal } \\
\text { diastole } \\
(n=206)\end{array}$ & $p$ \\
\hline Age (years) & $50.58 \pm 4.84$ & $51.26 \pm 3.68$ & 0.089 \\
\hline \multicolumn{4}{|l|}{$\operatorname{Sex}, N(\%):$} \\
\hline Male & $164(55.8 \%)$ & $90(43.7 \%)$ & $0.008 *$ \\
\hline Female & $130(44.2 \%)$ & $116(56.3 \%)$ & \\
\hline BMI $\left(\mathrm{kg} / \mathrm{m}^{2}\right)$ & $30.54 \pm 2.74$ & $29.25 \pm 3.35$ & $0.001 *$ \\
\hline $\begin{array}{l}\text { Duration of DM } \\
\text { (months) }\end{array}$ & $7.53 \pm 3.15$ & $6.85 \pm 3.28$ & $0.020 *$ \\
\hline Smoking, n (\%): & $123(41.8 \%)$ & $82(39.8 \%)$ & 0.649 \\
\hline \multicolumn{4}{|l|}{ Treatment, $n(\%)$ : } \\
\hline Insulin & $86(29.3 \%)$ & $80(38.8 \%)$ & \\
\hline $\mathrm{OHD}$ & $198(67.3 \%)$ & $121(58.7 \%)$ & 0.077 \\
\hline OHD \& insulin & $10(3.4 \%)$ & $5(2.4 \%)$ & \\
\hline HbA1c (\%) & $7.85 \pm 1.85$ & $7.47 \pm 1.21$ & $0.010 *$ \\
\hline Creatinine (mg/dl) & $0.857 \pm 0.167$ & $0.837 \pm 0.159$ & 0.179 \\
\hline Urea (mg/dl) & $29.35 \pm 5.32$ & $28.45 \pm 4.84$ & 0.054 \\
\hline Albumin (g/dl) & $4.11 \pm 0.555$ & $4.15 \pm 0.534$ & 0.421 \\
\hline $\mathrm{TC}(\mathrm{mg} / \mathrm{dl})$ & $201.65 \pm 30.5$ & $184.1 \pm 32.42$ & $0.000 *$ \\
\hline TG (mg/dl) & $108.11 \pm 26.81$ & $96.27 \pm 28.49$ & $0.000 *$ \\
\hline LDL (mg/dl) & $99.13 \pm 25.22$ & $91.44 \pm 24.28$ & $0.001 *$ \\
\hline HDL (mg/dl) & $46.81 \pm 7.95$ & $49.15 \pm 6.43$ & $0.001 *$ \\
\hline
\end{tabular}

*Significant difference level $<0.05$.

This table shows that BMI, DM duration, $\mathrm{HbA1c}, \mathrm{TC}, \mathrm{TG}$ and LDL were highly significant in DM-cases with LVDD in comparison to diabetics with normal LVDF. Meanwhile, HDL was low significance in DM-cases with LVDD. However, LVDD was significantly commoner in males.

Table (4): Multi-variate logistic regressions analyzing to determine the possible predictors of DD.

\begin{tabular}{lclc}
\hline Variable & OR & Sig. & $95 \%$ CI \\
\hline Age & 0.977 & 0.337 & $0.932-1.025$ \\
Male gender & 12.15 & 0.273 & $0.139-16.79$ \\
Smoking & 0.465 & 0.547 & $0.039-5.592$ \\
DM duration & 0.573 & 0.666 & $0.046-7.167$ \\
BMI & 1.214 & $0.027 *$ & $1.054-1.397$ \\
HbA1c & 1.267 & $0.009^{*}$ & $0.951-1.688$ \\
TC & 1.257 & $0.001 *$ & $1.019-1.550$ \\
TG & 1.588 & $0.033 *$ & $1.002-2.517$ \\
HDL & 0.865 & 0.201 & $0.541-0.988$ \\
LDL & 1.295 & $0.011 *$ & $0.836-1.387$ \\
\hline
\end{tabular}

This table shows that BMI, HbA1c, TC, TG and LDL were found to be significant predictors for DD. 


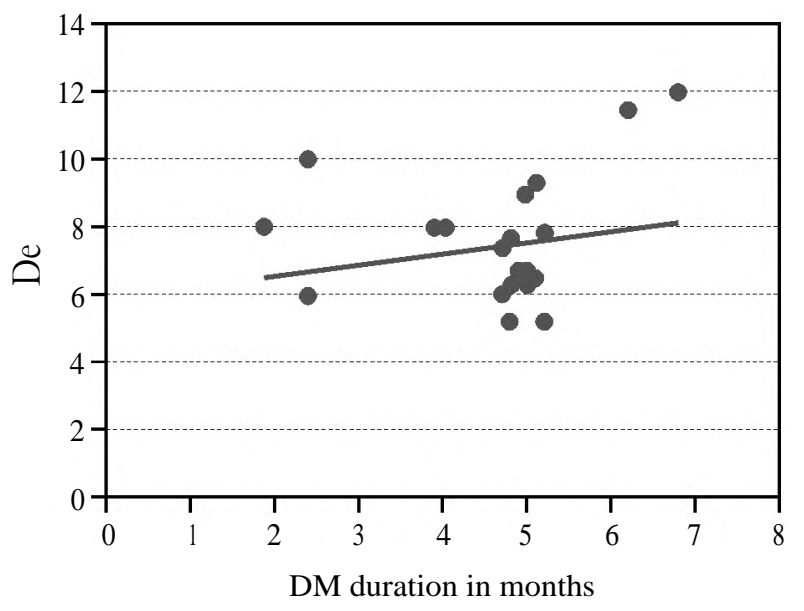

Fig. (1): Significant positive correlation between diastolic function and DM duration ( $p=0.001)$.

\section{Discussion}

Several researches have concluded that the HF incidence in DM-cases is elevated even in the nonpresence of HTN and CAD. Authors have concluded an elevated prevalence of pre-clinical DDbetween DM-cases. The evidence shows that myocardial damaging in DM-cases influences diastolic functions before the systolic functions. The pathogenesis of this LV-dysfunction in DM-cases is unclearly explained [15].

DM-II is one of the risk-factors for occurrence$\mathrm{HF}$ and rises the risk of morbidities and mortalities in cases with recognized disorder. Secular trends in the incidence of DM and HF estimate a rising load of disorder and underline the necessity for operative therapeutic approaches [16]

Diabetic cardio-myopathy was assumed as a nondependent cardio-vascular disorder, and several mechanisms, like micro-vascular disorders, autonomic dysfunctions, metabolic diseases, and interstitial fibrosis, were poroposed as causative parameters [17]

Many researches have confirmed evidences for pre-clinical LVDD in cases with DM nondependent of coronary disorders or HTN. The objective of our work was to investigate the occurrence and stages of LVDD and dyslipidemia in symptom less newly detected DM-II-cases.

This was a cross-sectional research; observational study was performed for 18 months, caseshave been sorted regarding their HbA1c levels into 2 groups: Group I: 300 patients with $\mathrm{HbA} 1 \mathrm{c}$ $\mathrm{HbA} 1 \mathrm{c} \geq 7.5$, and group II: 200 patients with $\mathrm{HbA} 1 \mathrm{c}$ HbA 1 c $<7.5$.
Moreover, we re-classified the studied group into 2 more subgroups regarding the existence or non-presence of LVDD.

In the current study, we revealed that there were nonstatistical change among groups regarding ages, gender, while we found that BMI and lipid profile (except HDL) were highly significant in DM-cases with $\mathrm{HbA} 1 \mathrm{c} \geq 7.5$ in comparison to diabetics with normal $\mathrm{HbA}$ 1c. Meanwhile, HDL was of low significance in DM-cases with $\mathrm{HbA} 1 \mathrm{c} \geq 7.5$. Table (1).

In agreement with the study of Alzahrani et al., [18] which concluded that there were 90 (43.69\%) cases in the group with $\mathrm{HbA} 1 \mathrm{c}$ level $<7 \%$, and 116 $(56.31 \%)$ cases in the group with $\mathrm{HbA} 1 \mathrm{c}$ level $>7 \%$. A nonsignificant change was found in any factorexcluding for TG levels ( $p$-value $=0.020)$ and $\mathrm{HbA} 1 \mathrm{c}(p$-value $<0.001)$.

In accordance with our findings, the report of Hassan Ayman et al., [19] which was a ross-sectional research included 100 non-hypertension, nonischemic cases who were a new detected with DMII within 1-yr (mean period from DM diagnosing $=7 \pm 4$-mths). The studied group exhibited no sex change with ages mean of $50 \pm 6$-yrs and $37 \%$ obesity. 66-cases (66\%) had evidently increased $\mathrm{HbA1c}$ level (group-II), they concluded that there were nonsignificant changes among both groups regarding ages, gender and all lipid profile excluding entire cholesterol and triglycerides which were high in group I, and HDL which was lower in cases who had noticeably increased HbA 1 c-levels.

Earlier detections of possible CVD in DMcasescould significantly decrease death from diabetic cardio-vascular complications. Echocardiography permits determinations of the morphological and functional features of the heart and canspecify pathological variations that rise the CVD risk [20].

In the current work, we found that LA size and volume index, de-acceleration time and E/e' were highly significant in DM-cases with $\mathrm{HbA} 1 \mathrm{c} \geq 7.5$ in comparison to diabetics with normal $\mathrm{HbA} 1 \mathrm{c}$. Meanwhile, E wave, E/A ratio and Iso-volumetric relaxation time were significantly lower in DMcases with HbA1c $\geq 7.5$. Moreover, there was a highly significance change among the groups concerning diastolic function grades. Table (2). This can be clarified by insulin resistances and successive hyper-insulinaemia which canexcitepro hypertrophic variations in the myocardium [21]. This in turn causes raised diastolic LV stiffness and raised cardio-myocyte hypertrophy that causes for cardio- 
myocyte latent tension that are nondependent of pressure over loads [22].

In the other hand the report of Hassan Ayman et al., [19] which revealed that there were nonstatistical significant differences between cases with $\mathrm{HbA} 1 \mathrm{c} \geq 7.5$ in comparison to diabetics with normal HbA1c. As regard each of ejection fraction, left atrium size, Left atrium volume index, E wave, E/A ratio, De-acceleration time, while Isovolumetric time of relaxation were highly significant in DM-cases with HbA1c $\geq 7.5$, and it was reported that E/e' was of low significance among DM-cases with $\mathrm{HbA1c} \geq 7.5$, as well they concluded that All cases had normal systolic functions, but 61 cases (61\%) had LVDD, with a high degree of DD in group-II.

In accordance with our results, Agrawal et al., [23] detected that the majority of his cases with LVDD (73\%) had reduced LV relaxation, $16 \%$ had a pseudo normal filling patterns and no cases had a preventive filling patterns.

In contrast to our findings, Seferovic-Mitrovic et al., [24] which studied 104 type 2 DM-cases (ages mean $55.4 \pm 9.1$-yrs, $64.4 \%$ men) with normal BP, pre HTN and arterial HTN stage-I. Research design involve basic lab valuation and cardiological workup (transthoracic Echo-cardiography and tissue Doppler, in addition to the exercise stress Echocardiography), and revealed LVDD in only $11 \%$ of his cases, and all of them had only impaired relaxations, which may be clarified on the basics of dissimilar study designs. Long-standing hyperglycaemia influences diastolic LV stiffness by multidirect and non-direct mechanisms.

Jain et al., [25] concluded that as HbA1c elevated, LVDD deteriorated. They revealed that 8 out of 16 cases with HbA $1 \mathrm{c}>9.5$ had grade-III LVDD. In contrast, only $34.3 \%$ of those with $\mathrm{HbA} 1 \mathrm{c}$ of 6.5-7.5 had LVDD.

Also, in accordance with our results, Kumar et al., [26] reported that cases with $\mathrm{HbA1c}>7.5 \%$ had a highprevalence of DDin comparison to $\mathrm{HbA} 1 \mathrm{c}$ $<7.5 \%$.

In accordance with our findings, Suresh et al., [27] revealed that cases with $\mathrm{HbA} 1 \mathrm{c}>8.1 \%$ had a high prevalence of DDin comparison to $\mathrm{HbA} 1 \mathrm{c}$ $<8.1 \%$. Moreover, LVDD was of more incidence in DM-cases with $\mathrm{HbA} 1 \mathrm{c}$ values $>8.1 \%$.

Myocardial damage in DM-cases influences diastolic functions before systolic functions. DD can be the most early marker of diabetes-induced increased cardio-myopathy, which leads to the progressive development of HF. In diabetes, along with increased collagen deposition, there is also an increase in the cross-linking of collagen fibers which contributes to a reduction in ventricular compliance. Apart from diabetes, DD may also be seen in patients with ischemic heart disorder, systemic HTN, cardio-myopathy, and valvular heart disorders [28].

The assessment of LV diastolic satisfying in adults of the American Indian Communities with DM-II mellitus in a populations-built samples of middle-ages and old adults by Liu et al., [29] concluded that DM-cases with anomalous LV diastolic filling had worse glycemic control as showed by high level of $\mathrm{Hb} \mathrm{A} 1 \mathrm{C}$ and fasting glucose than DM-cases with normal LV diastolic filling. Signifying that, DM, particularly with worse glycemic controlling, is non-dependently accompanying with atypical LV relaxations.

A case-control study by Patil et al., [5] performed at a tertiary care Hospital in Karad, from Jan. 2009 till Dec. 2009, showed $69(54.33 \%)$ of the total 127 cases had DD, and $11 \%$ among 100 controls revealed DD. cases with a longer period of DM (of 11-15-yrs) had a more elevated prevalence of DD. Cases with $\mathrm{HbA} 1 \mathrm{c}>7.5 \%$ had a more elevatedincidence of DD than cases with HbA1c $<7.5 \%$. At the end, the therapeutic managements of diastolic HF is, at minimumpartly, empirical and numerous researches, current or finished, have been planned to examinate the influence of ACE \& angiotensin inhibitors, and $\beta$-blockers.

Furthermore, in our study we further divided the studied cases regarding the existence or nonexistence of LVDD, and found that BMI, DM duration, HbA1c, TC, TG and LDL were highly significant in DM-cases with LVDDin comparison to diabetics with normal LVDF. Meanwhile, HDL was of low significance in DM-cases with LVDD. However, LVDD was significantly more common in males. Table (3). Also in our study, we revealed that there was significant positive association between diastolic function and DM duration. Table (4).

In Regards obesity as a confounder, over-weight and obesity are showed to be accompanying with anomalous LV re-modelling and then anomalous high E/e' ratio [30]. In Hassan Ayman et al., [19] study, only the WHR, as one of the obesity indices, was high in the group with LVDD, and cases with LVDD had dyslipidemia in comparison to those with ordinary LVDF. 
As said by Jain et al., [25] all cases with gradeII or III LVDD had a BMI $>25$.

However, in a study of Schannwell et al., [30] with a 87 cases revealed that even young DMcases and ordinary EF suffered from DD.

In accordance with the present findings, Patil et al., [5] concluded that out of 89-cases with HbA1c $<7.5 \%, 39(42.82 \%)$ had DD; and, out of 38 cases with HbA1c $>7.5 \%, 31(81.57 \%)$ had DD. Cases with HBA1c $>7.5 \%$ had more prevalent of DD, than cases with HBA1c $<7.5 \%$ (' $p$ '<0.02). Out of 23 cases with ages $<45$-yrs, $10(43.47 \%)$ had DD; and, out of 104-cases with ages $>45$-yrs, 61 $(58.65 \%)$ have DD. DD was highly significant in cases with ages $>45$-yrs, in comparison to ages $<45$-yrs (' $p<0.05)$. Total $78(61.41 \%)$ cases were with the period of DM from 6 to 10 -yrs, and 49 $(38.58 \%)$ were from 11 to 15 -yrs. Out of 78 $(61.41 \%)$ cases with DM periodfrom 6 to 10 -yrs, $32(41.02 \%)$ have DD. Out of $49(38.58 \%)$ cases with DM period from 11 to 15 -yrs, 37 (75.51\%) have $\mathrm{DD}$, cases with 11 to 15 -yrs DM period had more prevalence of DD $(p<0.02)$.

Masugata et al., [31] in their case-control research of 77 cases revealed that, the cardiac DD with no LV systolic dysfunctions in cases with well-controlled DM-II is connected neither to HTN nor LV hypertrophy, but rather to aging and the DM-II period.

Mishra et al., [32] in their case-control research of 71 DM-IIcases revealed that symptom less DMcases have decreased LV systolic and diastolic functions in comparison to controls. LV systolic and diastolic irregularities are related with the DMperiod and with DM micro-angiopathies, like retino-pathy and neuro-pathy.

Finally, we demonstrated that BMI, HbA1c, TC, TG and LDL were revealed to be significant prognosticators for DD. Table (4).

In comparison with the study of Hassan Ayman et al., [19] which reported that It concluded that WHR $(\mathrm{OR}=0.2, \mathrm{CI}=0.06-0.5, p$-value $=0.002)$ and HbA1c levels $(\mathrm{OR}=2.7, \mathrm{CI}=1.0-7.5, p$-value $=0.04)$ were the only prognosticators of reduced diastolic functions.

\section{Study limitations:}

Homeostatic model assessing index (HOMA) for examining fasting insulin concentrations isn'tmeasured in the current work because of incomes limitations. HOMA index is judged as a nondependent factor for DD. Furthermore, this cross-sectional research included a comparativelysome of cases in a single centre, also Lack of controls and following-up. Upcoming researches with larger sample sizes and a longitudinal cohort design involving controls are essential to confirmation our results.

\section{Conclusion:}

Diastolic dysfunction (DD) has a high prevalence in a new diagnosed DM-cases and looks to be associated positively with the HbA1c-levels, dyslipidaemia, obesity, and the DM period.

So as toadvance the present poor prognosing in DM-cases, the treatments of diastolic HF should be improved. DM-II-cases must be screened for subclinical DD by Echo-cardiography

\section{References}

1- KAZIK A., WILCZEK K. and POLON'SKI L.: Management of diastolic heart failure. Cardiol. J., 17: 558-65, 2010.

2- PAPPACHAN J.M., VARUGHESE G.I., SRIRAMAN R and ARUNAGIRINATHAN G.: Diabetic cardiomyopathy: Pathophysiology, diagnostic evaluation and management. World J. Diabetes, 4 (5): 177, 2013.

3- JIA G., DEMARCO V.G. and SOWERS J.R.: Insulin resistance and hyperinsulinaemia in diabetic cardiomyopathy. Nat. Rev. Endocrinol., 12 (3): 144, 2016.

4- WANG T.J., EVANS J.C., BENJAMIN E.J., LEVY D., LEROY E.C. and VASAN R.S.: Natural history of symptomless left ventricular systolic dysfunction in the community. Circulation, 108 (8): 977-98, 2003.

5- PATIL V.C., PATIL H.V., SHAH K.B., VASANI J.D. and SHETTY P.: Diastolic dysfunction in symptomlessDMII mellitus with normal systolic function. Journal of cardiovasculardisorder research; 2 (4): 213-222. https://doi.org/ 10.4103/0975-3583.89805, 2011.

6- KANE G.C., KARON B.L., MAHONEY D.W., REDFIELD M.M., ROGER V.L., BURNETT J.C., et al. Progression of left ventricular diastolic dysfunction and risk of heart failure. JAMA, 306: 856-863, 2011.

7- NAGUEH S.F., APPLETON C.P., GILLEBERT T.C., MARINO P.N., OH J.K., SMISETH O.A., et al.: Recommendations for the evaluation of left ventricular diastolic function by Echo-cardiography. European Journal of Echo-cardiography, 10: 165-93, 2009.

8- CHENG R.K., COX M., NEELY M.L., HEIDENREICH P.A., BHATT D.L., EAPEN Z.J., et al.: Outcomes in patients with heart failure with preserved, borderline, and reduced ejection fraction in the Medicare populatoin. Am. Heart J., 168: 721-730, 2014.

9- VENSKUTONYTE L., CHRISTINA JARNERT, LARS RYDEN, and BARBRO KJELLSTRÓM: Longitudinal Development of Left Ventricular Diastolic Function in DM-II-cases.Diabetes Care, 37: 3092-3097 | DOI: 10.2337/dc14-0779, 2014. 
10-Association A.D.: Classification and diagnosis of diabetes. Diabetes Care, 40 (Supplement 1): S11-S24, 2017.

11-HUXLEY R., MENDIS S., ZHELEZNYAKOV E., REDDY S. and CHAN J.: Body mass index, waist circumference and waist: Hip ratio as predictors of cardio-vascular risk-a review of the literature. Eur. J. Clin. Nutr., 64 (1): 16-22, 2010.

12- WILLIAMS B., MANCIA G., SPIERING W., AGABITI ROSEI E., AZIZI M., BURNIER M., et al.: 2018 ESC/ESH Guidelines for the management of arterial hypertension. Eur. Heart J., 39 (33): 3021-3104, 2018.

13- REINER Z ., CATAPANO A.L., DE BACKER G., GRAHAM I., TASKINEN M-R., WIKLUND O., et al.: ESC/EAS Guidelines for the management of dyslipidaemias: The Task Force for the management of dyslipidaemias of the European Society of Cardiology (ESC) and the European Atherosclerosis Society (EAS). Eur. Heart J., 32 (14): 1769-1818, 2011.

14- SHARMA S., RASHMEET SINGH, SIROHI T.R., SAURABH SINGHAL, ABHISHEK GUPTA and GIRISH DUBEY: Prevalence of left ventricular diastolic dysfunction in metabolic condition as assessed by Echocardiography. International Journal of Contemporary Medical Research, 7 (2): B 11-B 14, 2020.

15- DUNLAY S.M., MICHAEL M. GIVERTZ, DAVID AGUILAR, LARRY A. ALLEN, MICHAEL CHAN, AKSHAY S. DESAI, ANITA DESWAL, VICTORIA VAUGHAN DICKSON, MIKHAIL N. KOSIBOROD, CAROLYN L. LEKAVICH, ROZALINA G. MCCOY, ROBERT J. MENTZ and ILEANA L. PIÑA: DM-II Mellitus and Heart Failure: A Scientific Statement From the American Heart Association and the Heart Failure Society of America: This statement does not represent an update of the 2017 ACC/AHA/HFSA heart failure guideline update, nVol. 140, No. 7DM-II Mellitus and Heart Failure: A Scientific State, Originally published6June 2019https://doi.org/10.1161/CIR.0000000000000691Ci rculation, 140: e294-e324, 2019.

16- Centers for Disorder Control and Prevention. National Diabetes Statistics Report2017: Estimates of Diabetes and Its Burden in the United States (2017). https://. www.cdc.gov/diabetes/pdfs/data/statistics/nationaldiabetes-statistics-report.pdf. Accessed November 26.

17- FROM A.M., SCOTT C.G. and CHEN H.H.: Changes in diastolic dysfunction in diabetes mellitus over time. Am. J. Cardiol., 103: 1463-6, 2009.

18-ALZAHRANI S.H., BAIG M., AASHI M.M., AL-SHAIBI F.K., ALQARNI D.A. and BAKHAMEES W.H.: Association between glycated hemoglobin (HbAlc) and the lipid profile in DM-II-cases mellitus at a tertiary care hospital: a retrospective study. Diabetes Metab. Syndr. Obes., 12: 1639-1644, 2019.

19- HASSAN AYMAN K.M., ABDALLAH MAHMOUD A., ABDEL-MAGEED EMAN A., et al.: Correlation between left ventricular diastolic dysfunction and dyslipidaemia in symptomless patients with newly diagnosedDM-II mellitus. Egypt J. Intern. Med., 33, 8. https://doi.org/ 10.1186/s43162-021-00037-0, 2021.

20- ZHAO Z., HOU C., YE X. and CHENG J.: Echocardiography Changes in Newly Diagnosed DM-II Mellitus Patients with and without Hypertension. Medical science monitor: International medical journal of exper- imental and clinical research; 26, e918972. https://doi.org/ 10.12659/MSM.918972, 2020.

21- POORNIMA I.G., PARIKH P. and SHANNON R.P.: Diabetic cardio-myopathy: The search for a unifying hypothesis. Circ. Res., 98 (5): 596-605 Return to ref 32 in article, 2006.

22- VAN HEEREBEEK L., HAMDANI N., HANDOKO M.L., FALCAO-PIRES I., MUSTERS R.J., KUPREISHVILI K., et al.: Diastolic stiffness of the failing diabetic heart: Importance of fibrosis, advanced glycation end products, and myocyte resting tension. Circulation, 117 (1): 43-51, 2008.

23- AGRAWAL V., AGRAWAL A., DWIVEDI A.N. and TRIPATHI K.: Correlation between 2D Echo-cardiography and multidetector row CT for early detection of diastolic dysfunction in normotensive DM-cases. J. Clin. Diagn. Res., 10 (8): OC27-OC30, 2016.

24- SEFEROVIC-MITROVIC J.P., LALIC N.M., VUJISICTESIC B., LALIC K., JOTIC A., RISTIC A.D., et al.: Symptomlesscardio-vascular manifestations in diabetes mellitus: Left ventricular diastolic dysfunction and silent myocardial ischemia. Srp. Arh. Celok. Lek., 139 (9-10): 599-60, 2011.

25- JAIN S., NAWAL C., SINGH A., CHEJARA R.S., BARASARA S. and MARKER S.: Echo-cardiography evaluation of left ventricular diastolic dysfunction in recently diagnosed DM-II mellitus. Int. J. Res. Med. Sci., 6 (5): 1691-1693, 2018.

26- KUMAR V.S., SREELATHA M., RAMESH K. and SHEKAR G.C.: Study of left ventricular diastolic dysfunction in DM-II mellitus patients. Int. J. Sci. Study, 5 (4): 219-224, 2017.

27- SURESH G., ALVA R., PRAKASH P. and SAYA R.P.: Prevalence of symptomless left ventricular diastolic dysfunction in type 2 DM-cases and healthy controls: A comparative study. Arch. Med. Health Sci., 5 (1): 30, 2017.

28- GOLDIN A., BECKMAN J.A., SCHMIDT A.M. and CREAGER M.A.: Advanced glycation end products. Sparking the development of diabetic vascular injury. Circulation, 114: 597-605, 2006.

29- LIU J.E., PALMIERI V., ROMAN M.J., BELLA J.N., FABSITZ R., HOWARD B.V., et al.: The impact of diabetes on left ventricular filling pattern in normotensive and hypertensive adults: The Strong Heart Study. J. Am. Coll. Cardiol., 37: 1943-9, 2001.

30- SCHANNWELL C.M., SCHNEPPENHEIM M., PERINGS S., PLEHN G. and STRAUER B.: Left ventricular diastolic dysfunction as an early manifestation of diabetic cardio-myopathy. Cardiology, 98 (1-2): 33-39, 2002.

31- MASUGATA H., SENDA S., GODA F., YOSHIHARA Y., YOSHIKAWA K., FUJITA N., et al.: Left ventricular diastolic dysfunction in normotensive DM-cases in various age strata. Diabetes Res. Clin. Pract., 79: 91-6, 2008.

32- MISHRA T.K., RATH P.K., MOHANTY N.K. and MISHRA S.K.: Left ventricular systolic and diastolic dysfunction and their relationship with micro-vascular complications in normotensive, symptomlessDM-II-cases mellitus. Indian Heart J., 60: 548-53, 2008. 


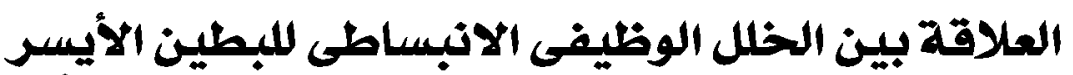

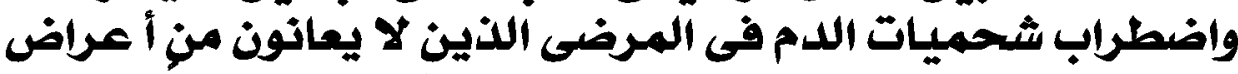

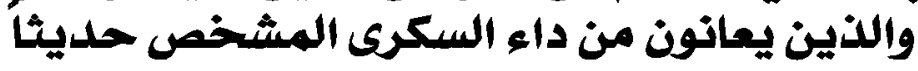

الخلفية: أن تكرد قصدد القلب فى حالات داء السكرى مرتفع حتى فى علم وجود ارتفاع في ضغط الدم واضطراب الشريان التاجى.

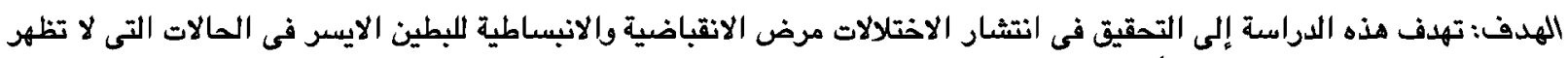

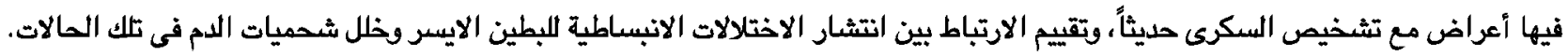

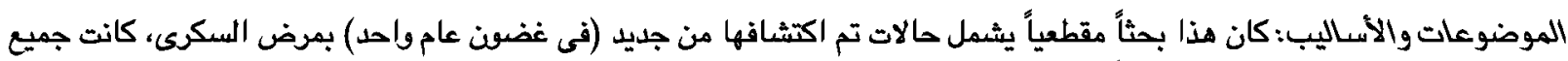

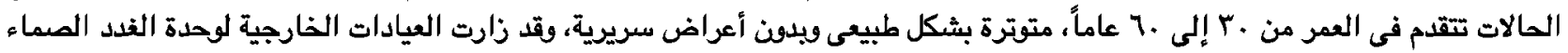

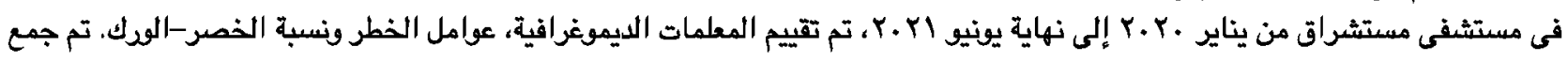
عينات الدم للتحليل المعملى. تم إجراء تخطيط صدى القلب الثامل لتقييم الوظائف الانقباضية والانبساطية فئية.

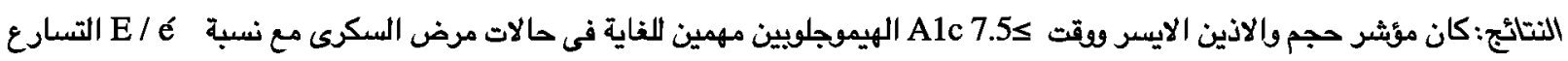

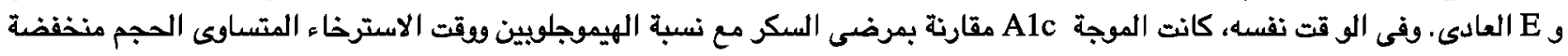

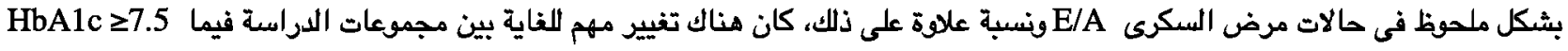
مع يتعلق بدرجات الوظيفة الانبساطية.

الخلاصة: الخلل الانبساطى له انتشار كبير فى حالات مرض، وعسر A1c السكرى المكتشفة حديثاً ويبدو أنه مرتبط بثكل إيجابى

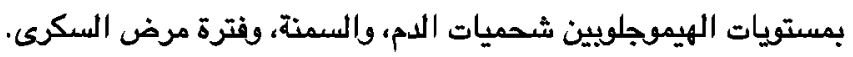

